\title{
An Analysis of Wage Gap Between Chinese State-owned Enterprises and Non-state-owned Enterprises
}

\author{
Zhang Kexin \\ Beijing Jiaotong University, China \\ 15120560@bjtu.edu.cn
}

Keywords: Labor economics, Wage gap, State-owned Enterprises, Industry, Monopoly

\begin{abstract}
This paper, by using CHIP2013 urban household survey data, studies wage gap between Chinese state-owned enterprises and non-state-owned enterprises. So this study uses the descriptive statistics and OLS regression, considering enterprise characteristics (such as ownership structure and region), personal characteristics (such as education years, tenure, gender, party member status, health and employment form) and industry characteristics (such as industry and industry monopoly situation) factors, to compare the differences of influence in Chinese state-owned enterprises and non-state-owned enterprises. The results show that the state-owned enterprise salary actually is higher than the non-state-owned enterprises; Above factors on the influence of the state-owned enterprises and non-state-owned enterprises employee wages is different; The wage gap between the industry, especially the wage gap between monopoly and competition industry is very big. Combined with the enterprise ownership, the state-owned enterprise's wage in the monopoly industries is much higher than non-state-owned enterprise's wage in competition industry. In the future, the reform of state-owned enterprise salary system should be pay more attention to strengthen the management and supervision of state-owned enterprises in monopoly industries.
\end{abstract}

\section{Introduction}

The wage gap is an important factor affecting people's happiness, national development and social stability. If the wage gap is too large, it will enhance the sense of social injustice, and even endanger national development and social stability. In recent years, there is increasing pressure on the labor market competition, and through study, more and more scholars found that Chinese state-owned enterprises have more higher income and better benefits than Non - state - owned enterprises.In 1995, 2002, 2007 and 2014, the hourly wages of Chinese state-owned enterprises were $24.19 \%, 26.64 \%$, $11.93 \%$ and $12.09 \%$ respectively higher than those of non-state-owned enterprises. The reasons for studying the wage gap between state-owned enterprises and non-state-owned enterprises can help us to deepen understanding of the income gap and provide a theoretical basis for the reform of the wage system of Chinese state-owned enterprises in the future.

Looking at the existing research on the wage difference between state-owned enterprises and non-state-owned enterprises, most of them are considered for a certain kind of factors, and few factors such as enterprise characteristics, personal characteristics and industry characteristics are taken into account. Moreover, many of the literature are written from the perspective of labor needs (business or industry), the use of business or industry data is carried out, the empirical analysis on impact of wage differences is conducted, and less literature uses the micro-data of workers to consider. In addition, many of the independent variables of the literature are the annual gloss wage of the laborer rather than the hourly wage rate, which ignores the possibility of a difference in the total wage income due to differences in labor time. Therefore, it is expected that this paper makes the empirical analysis on the gap of the hourly wage rate between china's state-owned enterprises and non-state-owned enterprises from the perspective of the labor supply of the workers, taking into account the characteristics of enterprises, personal characteristics and industry characteristics and other factors and under the conditions of the industry. 


\section{System Background and Literature review}

2.1 System Background. At present, the Chinese market economy has developed rapidly, in which the state-owned economy is still the main part of the market economy, but the non-state-owned economy has become a very important force in the market economy. At the same time, government power has played a decisive role in economic development. In the current economic pattern, the wages of Chinese state-owned enterprises and non-state-owned enterprises may be divided in the level of the nature of equity ${ }^{[1]}$.The reasons can be broadly divided into the following three ones: First, the business objectives of state-owned enterprises and non-state-owned enterprises are different; Second, the external environment of the business on state-owned enterprises and non-state-owned enterprises is different; Third, state-owned enterprises may have problems on insider control. If the insider in the state-owned enterprises holds control of the business and lacks the effective oversight mechanism, the surplus income of the enterprises is likely to be on his own and he is more likely to pay high wages to the employees to try to form an alliance. While the professional managers of non-state-owned enterprises will be subject to more incentive and supervision, so they are more likely to maximize the interests of shareholders as the goal.

According to the above analysis, it can be drawn from this paper that in the current economic environment and political conditions, the Chinese state-owned enterprises pay higher wages.

2.2 Literature Review. The reasons for the wage gap between Chinese state-owned enterprises and non-state-owned enterprises are very complex, among which, there are several aspects to be paid with much attention such as the nature of equity, human capital and the issue on whether there are monopolies within the industry.

The wage difference among the enterprises with different equity nature. Xia Qingjie, Li Shi, etc. (2012) used the town household survey data of Chinese Household Income Project (CHIP) to study the income distribution effect before and after the reform of state-owned enterprises. They thought that after the completion of the reform of downsizing for efficiency on the state-owned enterprises, there were many state-owned monopoly enterprises, whose wages were much higher than the non-state-owned enterprises, so the urban wage income gap has been expanded ${ }^{[2]}$.

Laborers' Differences in Human Capital. Cai Fang, Du Yang (2000), Guo Jianxiong (2005) and Sun Baiyi (2005) all argued that the human capital gap caused the main reason for the income gap in China.The study results of Jiao Binlong (2011) showed that the larger the human capital stock in China were, the greater the income gap was, but he believed that the impact of human capital on income will be affected by economic environment and other factors such as policy intervention ${ }^{[3]}$.

There is a huge gap among wages in different industries. Many scholars believe that the lack of market performance and government functions has led to differences in industry wages. Luo Chuliang and Li Shi (2007) calculated the wage function by using more than 300 industrial data of the national first economic census data in 2004 and found that the wage level was proportional to the education level of the laborers and was inversely proportional to the degree of competition ${ }^{[4]}$.

\section{Variable Setting and Descriptive Statistics}

This paper uses the data from the CHIP2013 of Chinese Household Income Project Survey to carry out research. The survey includes the number of years of education of respondent, length of service, gender, health status, forms of employment, size of enterprises, areas and monopolies of the industry. The survey is very rich in the content, so in the measurement analysis of the paper, many variables that represent the individual characteristics of the laborer, the characteristics of the enterprise and the characteristics of the industry can be used to be investigated.

3.1 Variable Settings. The dependent variable is set as follows. In the wage function, the natural logarithm of the hourly wage rate of workers is used as the dependent variable. According to the relevant setting of the questionnaire, the wage is defined as the part of the wage income (including various monetary subsidies) of the job in 2013 and the conversion of the physical food and housing 
subsidies into the currency, excluding the financial property and the transfer of income, and then the total annual wage is divided by the annual labor time 3 to calculate the hourly wage rate.

The setting of the independent variable is as follows. First, set the variables that represent the human capital, respectively, the number of years of experience( years of experience $=$ age- the number of years of education-6), the number of years of education. Second, according to previous analysis, gender, health status and other personal characteristics which have an impact on wages, set up the dummy variable on behalf of these elements. Third, set the dummy variable that represents the form of employment of the laborer. Fourth, set the enterprise ownership, enterprise size, business areas and other factors dummy variables which represent the enterprise characteristics. The forms of enterprise ownership are state-owned enterprises and non-state enterprises (including collective enterprises, Sino-foreign joint ventures or wholly foreign-owned enterprises, private enterprises, individuals and others. Enterprises are divided into small-scale enterprises $(1 \sim 100$ person), medium-sized enterprises (101 to 1,000 person), large-sized enterprises (more than 1,000 person). The business area is divided into developed areas and other areas. Finally, set the dummy variable of industry nature. 19 industry dummy variables are set up in accordance with industry classification of CHI2013, and in terms of industry nature, it is divided into monopoly industries and competitive industries.

Table.1 Variable Set Table

\begin{tabular}{|c|c|}
\hline & Variable name \\
\hline dependent variable & The hourly wage rate \\
\hline \multirow{2}{*}{ Human capital } & Years of Education \\
\hline & Years of experience \\
\hline \multirow{2}{*}{ Personal characteristics } & Female \\
\hline & Healthy \\
\hline Employment form & Regular employment \\
\hline \multirow{3}{*}{ Enterprise scale } & Small-scale enterprises \\
\hline & Medium-sized enterprises \\
\hline & Large-sized enterprises \\
\hline Form of ownership & State-owned enterprise \\
\hline Region & Developed region \\
\hline Industry nature & Monopoly industry \\
\hline \multirow{18}{*}{ Industry } & Agriculture, forestry, animal husbandry and fishery \\
\hline & The mining industry \\
\hline & Manufacturing industry \\
\hline & Electricity, gas and water production and supply industry \\
\hline & Construction industry \\
\hline & wholesale and retail \\
\hline & Transportation, warehousing and postal services \\
\hline & Accommodation and catering industry \\
\hline & $\begin{array}{c}\text { Information transmission, software and information } \\
\text { technology services }\end{array}$ \\
\hline & The financial industry \\
\hline & real estate \\
\hline & Leasing and business services \\
\hline & Resident services, repair and other services \\
\hline & Education \\
\hline & $\begin{array}{l}\text { Public administration, social security } \\
\text { and social organization }\end{array}$ \\
\hline & Electricity, gas and water production and supply industry \\
\hline & Construction industry \\
\hline & wholesale and retail \\
\hline
\end{tabular}


Use It is worthwhile mentioning the industry classification. According to the project of questionnaire, 19 kinds of industry samples are obtained according to the industry large classification criteria. In order to use the sample data as effective as possible to carry out empirical analysis, this paper defines the monopoly industry and the competitive industry according to the following three standards ${ }^{[5]}$. The first standard is a reference to the classification standard of previous studies on European and American and China. The second standard is to classify it according to the proportion of the total number of labor force of state-owned enterprises in the industry accounting for the total number of labor force in the industry. It is intended to consider the particularity of China's monopoly industries. In other countries with developed market economies, monopoly industry are mostly caused by commodity monopolies or natural monopolies, but in China, in addition to the above two reasons, it may also lead to a monopoly due to some administrative system. It can be argued that the greater the proportion of the labor force in a state-owned enterprise in an industry is, the stronger the administrative monopoly of the industry is. The proportion of number of labor force in state-owned enterprises in each industry can refer Table 2 of this paper. The third standard is based on the difficulty of the labors freely enters into the industry. According to these three standards, in the analysis of this paper, the mining industry, electricity, gas and water production and supply industry, transportation, warehousing and postal services, the financial industry are taken as a monopoly industry, and these industry are used as competitive industry to conduct research such as agriculture, forestry, animal husbandry, Manufacturing, construction, wholesale and retail, accommodation and catering, information transmission, software and information technology services, real estate, leasing and services, residential services, repairs and other services, education, public administration, social security and social organizations, and other industries with less samples are removed.

Table.2 Monopoly Industry and Competitive Industry Classification

\begin{tabular}{cc}
\hline Industry name & Industry nature \\
\hline Agriculture, forestry, animal husbandry and fishery & Competitive \\
\hline The mining industry & Monopoly \\
\hline Manufacturing industry & Competitive \\
\hline Clectricity, gas and water production and supply industry & Monopoly \\
\hline wholesale and retail & Competitive \\
\hline Transportation, warehousing and postal services & Competitive \\
\hline Accommodation and catering industry & Monopoly \\
\hline Information transmission, software and information & Competitive \\
\hline technology services & Competitive \\
\hline real estate & Monopoly \\
\hline Leasing and business services & Competitive \\
\hline Resident services, repair and other services & Competitive \\
\hline Education & Competitive \\
\hline Public administration, social security and social organization & Competitive \\
\hline Descriptive & Competitive \\
\hline
\end{tabular}

3.2 Descriptive Statistics. The following is a statistical description of the variables of the state-owned enterprises and non-state enterprises in Table 1, which are described in terms of the nature of ownership and the nature of the industry. Table 3 shows the statistical description on the relationship among the hourly wage rate, the human capital factor (the number of years of education and the number of years of experience), the individual characteristics (female and health status), the form of employment, the size of enterprises (small-sized enterprises, medium-sized enterprises and 
large- sized enterprise), regional, industry nature made by Chinese state-owned enterprises and non-state-owned enterprises respectively and data occupancy or mean and standard deviation are listed.

Table.3 State-owned Enterprises and Non-state-owned Enterprise Data Statistical Description

\begin{tabular}{|c|c|c|c|}
\hline \multirow{2}{*}{\multicolumn{2}{|c|}{ Variable name }} & State-owned enterprise & $\begin{array}{l}\text { Non-state-owned } \\
\text { enterprises }\end{array}$ \\
\hline & & $\begin{array}{c}\text { Mean ( standard } \\
\text { deviation) } \\
\text { or proportion }\end{array}$ & $\begin{array}{c}\text { Mean ( standard } \\
\text { deviation) } \\
\text { or proportion }\end{array}$ \\
\hline \multicolumn{2}{|c|}{ The hourly wage rate } & $22.04(18.01)$ & $16.42(18.96)$ \\
\hline \multirow{2}{*}{ Human capital } & Years of Education & $12.40(2.99)$ & $10.97(3.17)$ \\
\hline & Years of experience & $21.93(11.02)$ & $22.27(12.16)$ \\
\hline \multirow{2}{*}{$\begin{array}{c}\text { Personal } \\
\text { characteristics }\end{array}$} & Female & $34.17 \%$ & $46.12 \%$ \\
\hline & Healthy & $98.77 \%$ & $98.17 \%$ \\
\hline $\begin{array}{l}\text { Employment } \\
\text { form }\end{array}$ & Regular employment & $83.19 \%$ & $33.84 \%$ \\
\hline \multirow{3}{*}{$\begin{array}{l}\text { Enterprise } \\
\text { scale }\end{array}$} & Small-scale enterprises & $27.84 \%$ & $73.60 \%$ \\
\hline & $\begin{array}{c}\text { Medium-sized } \\
\text { enterprises }\end{array}$ & $39.07 \%$ & $19.96 \%$ \\
\hline & Large-sized enterprises & $33.08 \%$ & $6.44 \%$ \\
\hline Region & Developed region & $34.85 \%$ & $55.59 \%$ \\
\hline Industry nature & Monopoly industry & $49.83 \%$ & $12.35 \%$ \\
\hline
\end{tabular}

The following several conclusions can be drawn from the observation of Table 3 .

First, from the hourly wage rate, the hourly wage rate of Chinese state-owned enterprises is higher than that of non-state-owned enterprises, and the standard deviation of hourly wage rate of non-state-owned enterprises is greater than that of state-owned enterprises. It can be inferred that although the hourly wage rate of state-owned enterprises is greater than that of non-state enterprises, the wages of state-owned enterprises are relatively concentrated, and the wage difference among employees of non-state-owned enterprises is even greater.

Second, from the perspective of human capital, Chinese state-owned enterprises are more educated than non- state-owned enterprises, and the standard deviation is also smaller than nonstate-owned enterprises. This shows that employees of state-owned enterprises are generally more educated than that of non-state-owned enterprises. The years of experience of state-owned enterprises are slightly less than the years of experience of non-state-owned enterprises, but the difference is not much greater and its standard deviation is greater than that of non-state-owned enterprises.

Thirdly, from the other personal characteristics, the proportion of female employees in state-owned enterprises $(34.17 \%)$ is lower than that of non-state-owned enterprises $(46.12 \%)$. In terms of health conditions, most workers are healthy, but workers in state-owned enterprises are slightly healthier than those of non-state-owned enterprises.

Fourth, look at the scale of the enterprise. It can be seen that the state-owned enterprises in China is shown more in the enterprise scale of medium-sized enterprises (39.07\%) and large-sized enterprises (33.08\%), and less in small-sized enterprises (27.84\%).But the trend of non-state-owned enterprises is very obvious. Small-sized enterprises in non-state-owned enterprises accounts for $73.60 \%$, medium-sized enterprises accounts for $19.96 \%$, and large-sized enterprises accounts for only $6.44 \%$. 
Fifth, the proportion of state-owned enterprises in developed areas was $34.85 \%$, significantly lower than $55.59 \%$ of that in non-state-owned enterprises. This shows that more non-state-owned enterprises exist in the developed areas.

\section{The Model and Results of Quantitative Analysis}

Based on the analysis of the wage gap between state-owned enterprises and non-state-owned enterprises, it is estimated that the wage function of Chinese state-owned enterprises and non-state-owned enterprises is respectively:

$$
\begin{gathered}
\operatorname{Ln} W_{S O E, i}=X_{S O E, i}^{\prime} \beta_{S O E}+u_{S O E, i} \\
L n W_{N S O E, i}=X_{N S O E, i}^{\prime} \beta_{N S O E}+u_{N S O E, i}
\end{gathered}
$$

Among them, the subscript $S O E$ means state-owned enterprises, NSOE means non-state-owned enterprises. $L n W$ represents the natural logarithm of the hourly wage rate, $X$ representing the various variables vectors that affect wages. $\beta$ is the coefficient vector of various variables, and $u$ is the disturbance items of the equation.

Table 4 shows the OLS estimates of the wage function.

Table.4 OLS Estimates of Wage Function

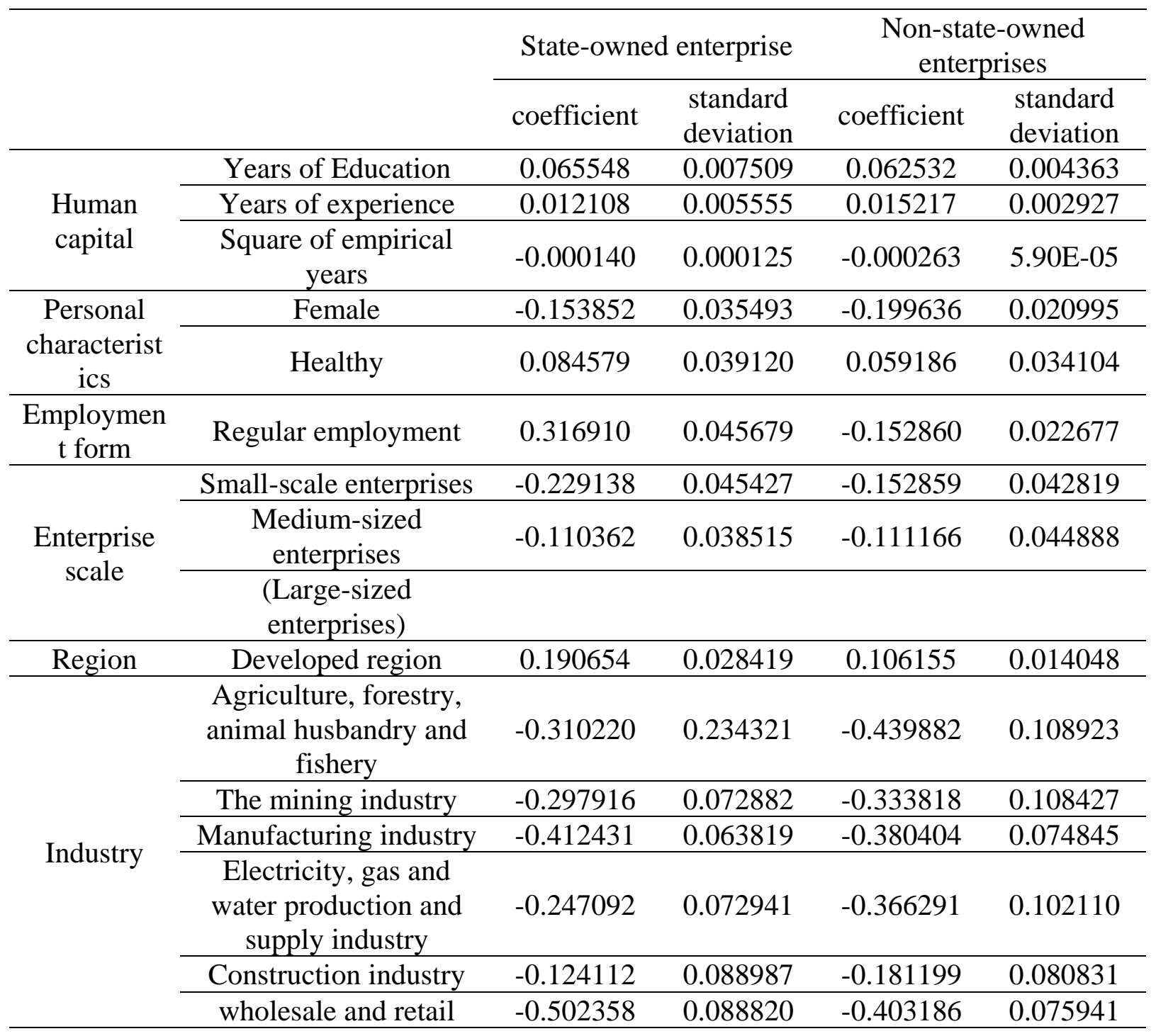




\begin{tabular}{|c|c|c|c|c|}
\hline $\begin{array}{c}\text { Transportation, } \\
\text { warehousing and postal } \\
\text { services }\end{array}$ & -0.294900 & 0.067190 & -0.235579 & 0.081203 \\
\hline $\begin{array}{l}\text { Accommodation and } \\
\text { catering industry }\end{array}$ & -0.529910 & 0.129165 & -0.356801 & 0.082065 \\
\hline $\begin{array}{c}\text { Information } \\
\text { transmission, software } \\
\text { and information } \\
\text { technology services }\end{array}$ & -0.246129 & 0.084188 & -0.180620 & 0.085007 \\
\hline ( The financial industry) & & & & \\
\hline real estate & -0.213207 & 0.162118 & -0.250188 & 0.097784 \\
\hline $\begin{array}{l}\text { Leasing and business } \\
\text { services }\end{array}$ & -0.186444 & 0.137306 & -0.371800 & 0.083003 \\
\hline $\begin{array}{l}\text { Resident services, repair } \\
\text { and other services }\end{array}$ & -0.254097 & 0.099471 & -0.506307 & 0.076358 \\
\hline Education & -0.337706 & 0.232513 & -0.296803 & 0.100316 \\
\hline $\begin{array}{l}\text { Public administration, } \\
\text { social security and } \\
\text { social organization }\end{array}$ & -0.404191 & 0.122214 & -0.590574 & 0.089884 \\
\hline Constant term & \multicolumn{2}{|c|}{1.647343} & \multicolumn{2}{|c|}{1.969828} \\
\hline$R^{2}$ & \multicolumn{2}{|c|}{0.249904} & \multicolumn{2}{|c|}{0.218978} \\
\hline F-measure & \multicolumn{2}{|c|}{19.89254} & \multicolumn{2}{|c|}{45.82938} \\
\hline -test（F>prob） & \multicolumn{2}{|c|}{0.000000} & \multicolumn{2}{|c|}{0.000000} \\
\hline
\end{tabular}

Compare the every data in Table 4 and get the following conclusions.

First, consider the impact of human capital. In terms of the estimated coefficient of the number of years of education, no matter in state-owned enterprises or non-state-owned enterprises, wages will increase correspondingly with the increase in the number of years of education of worker. However, it can be seen by comparing the rate of return on education of two of them that the rate of return on education of state-owned enterprises $(6.55 \%)$ is higher than that of non-state-owned enterprises (6.25\%). In terms of the number of years of experience, it is the opposite of the number of years of education. The impact of years of experience in non-state-owned enterprises on wages $(1.52 \%)$ is greater than that of state-owned enterprises $(1.21 \%)$.

Second, from the personal characteristics point of view. In state-owned enterprises, women's wages are $15.39 \%$ lower than men's, while in non-state-owned enterprises, women's wages are $19.96 \%$ lower than men. Healthy persons among state-owned enterprises is $32 \%$ higher than that of non-healthy people, while the number of healthy workers in non-state-owned enterprises are $16.85 \%$ higher than that of non-health workers and less than state-owned enterprises.

Third, look at the form of employment. Wages of formal employer in state-owned enterprises and non-state-owned enterprises are much higher than that of the informal employer, the gap was 31.69\% of state-owned enterprises, and $15.29 \%$ of non-state-owned enterprises. The analysis suggests that the wage gap between formal and informal workers in state-owned enterprises is greater than that of non-state-owned enterprises. In general, competition will lead to wage convergence when the other elements, including human capital are the same. While the number of non-state-owned enterprises in the competitive industry is greater than that of state-owned enterprises, leading to a large gap in the wage gap between formal and informal employment in state-owned enterprises .

Fourth, regarding the enterprise scale. No matter whether it is the state-owned enterprises or non-state-owned enterprises, the larger the scale of enterprises is, the higher the trend of wages is, but the wage gap of state-owned enterprises in small and medium-sized enterprises is greater than non-state-owned enterprises.

Fifth, from the perspective of the area. State-owned enterprises in the developed areas are $19.07 \%$ higher than those of state-owned enterprises in underdeveloped areas, while non-state-owned 
enterprises in the developed areas are $10.62 \%$ higher than those of non-state-owned enterprises in the underdeveloped areas.

Sixth, look at the industry monopoly. Even in each industry, under the same assumptions of workers' human capital, personal characteristics, forms of employment, employment size, ownership and regional characteristics, there are still differences among the industry wage. For example, from the estimated coefficients for each sector, it can be seen that other sectors are lower than the financial sector as a reference group. Compared with the financial industry in which the control group belongs to the monopoly industry, the wages of the manufacturing, wholesale and retail and resident services, maintenance and other services sectors in the competitive industries are lower than $41.24 \%$ and $38.04 \%, 50.24 \%$ and $40.82 \%, 25.41 \%$ and $50.63 \%$ of financial sector respectively. There is also a wage gap within the monopoly industry. For example, the mining industry with the same monopoly, both in state-owned enterprises and non-state-owned enterprises, is lower than the financial industry respectively, $29.79 \%$ for state-owned enterprises, and $33.38 \%$ for non-state-owned enterprises.

\section{Summary}

Through the above analysis, it is concluded that the employees' wages are institutionalized affected by the difference factors between the state-owned enterprises and the non-state-owned enterprises, such as the specific business environment, the purpose of the business and the internal control system, and the wages of employees of the non-state-owned enterprises are lower than the wage of the state-owned enterprises employees.

This paper provides some suggestions on the current situation of the reform of state-owned enterprises in China through the study of the wage gap between state-owned enterprises and non-state-owned enterprises. One of the reasons for the successful establishment of modern enterprises is to match the wage system of employees, establish appropriate enterprise employee wage system and rationalize the labor relations of employees through the modern enterprise reform. The specific state-owned enterprise enterprise reform is divided into two aspects, one for enterprises related to the national economic lifeline, such as water, electricity, defense science and technology and other countries must share the enterprise, senior management "personality" mechanism can be used, namely "state-owned assets manager professionalization", so that it is not to retain the characteristics of administrative officials, and state-owned enterprises is not linked to the profit distribution. When the profits are damaged in the actual state-owned enterprises, they will not sit still and the senior management of the staff will improve employee Wage Performance System, establish the corresponding prevention and control mechanisms and the competent national authorities should strengthen the supervision of their enterprises and improve the work efficiency mechanism and put an end to the loss of state assets caused by the system and mismanagement in the state-owned enterprise. Further realize the salaries of state-owned enterprises from total amount control to labor cost control and ultimately make the span of wage level of state-owned enterprises and social wage level gradually narrowed. Second, for non-national lifeline enterprises, the shareholding system reform could be taken, and the property rights are stripped out from the national system to realize the clear redistribution of enterprise owners through market mechanism and enhance the liquidity of state assets.

\section{References}

[1] Lu Zhengfei, Wang Xiongyuan, Zhang Peng, Whether State-owned Enterprises Pay Higher Wages, vol. 3, Economic Research Journal, 2012, pp. 28-39.

[2] Xia Qingjie, Li Shi,Song Lina, The Income Distribution Effect of the Wage Structure and the Change of Employment Scale:1998-2007, vol. 6, Economic Research Journal, 2012, pp. 127-142. 
[3] Jiao Binlong, The Effect of Human Capital on the Income Gap, vol. 5, Chinese Journal of Population Science, 2011, pp. 16-25.

[4] Luo Chuliang, Li Shi, Human capital, industry characteristics and income gap--Based on the experience of the first national economic census data, vol. 10, Management World, 2007, pp. 19-30.

[5] Ma Xinxin, The Division of Labor Market--An Empirical Analysis of Wage Differentials Between Monopoly and Competitive Industries, vol. 1, China Labor Economics, 2011, pp. 44-82.

[6] Ye Linxiang, Li Shi, Luo Chuliang, Industry monopoly, ownership and wage gap, vol. 4, Management World, 2011, pp. 26-36.

[7] Masayuki Morikawa, A comparison of the wage structure between the public and private sectors in Japan, vol. 39, Journal of The Japanese and Internatinal Economies, 2016, pp. 73-90. 